\title{
Synthesis and Characterization of Some Transition Metal Complexes of Substituted Pyrazol Aldehyde and $O$-Amino Phenol
}

\author{
ANITA SHARMA* and MANISH SHAH \\ Chemical Research Laboratory, Department of Chemistry, \\ Saurashtra University, Rajkot, Gujarat, India \\ anitagaur08@yahoo.com
}

Received 12 December 2014 / Accepted 29 December 2014

\begin{abstract}
The complexes of $\mathrm{Cu}(\mathrm{II})$ and $\mathrm{Co}(\mathrm{II})$ with Schiff base derived from 3-(3-substituted)-1phenyl-1 $H$-pyrazole-4-carbaldehyde and $o$-amino phenol have been prepared and characterized by Elemental analysis, molar conductance, magnetic susceptibility, Mass IR, UV-Visible spectroscopic technique and thermo gravimetric analysis. The ligand was found to be bidentate ligand. $\mathrm{Cu}(\mathrm{II})$ and $\mathrm{Co}(\mathrm{II})$ coordinate with the ligand through both oxygen of the phenol group and nitrogen of $-\mathrm{HC}=\mathrm{N}$ azomethine. The solubility test on the metal complexes revealed their solubility in DMF and DMSO. The molar conductance of the complexes measured is indicating their non-electrolytic nature. Magnetic moment and spectroscopic studies suggested the octahedral geometries of the complexes.
\end{abstract}

Keywords: Pyrazol, Octahedral geometry, NMR, Mass

\section{Introduction}

In recent years, there has been enhanced interest in the synthesis and characterization of transition metal complexes containing Schiff bases as ligands due to their importance as catalysts in many reactions ${ }^{1-6}$. Transition metal Schiff base complexes are used in various fields, such as medicine, agriculture, industries. There have been of considerable current interests to develop the chemistry of transition metal complexes those capable of cleaving DNA at specific sites, which play a major role in genomic research and photodynamic therapy of cancer $^{7,8}$. Pyrazoles are distinguished by their properties as biological agents ${ }^{9}$ and ligands in synthesis ${ }^{10}$. Pyrazol containing Schiff bases are widely used as chelating ligand for transition metal complexes. In this work, we report the results of our studies on the synthesis, spectral properties of $\mathrm{Cu}(\mathrm{II})$ and $\mathrm{Co}(\mathrm{II})$ complexes of Schiff base of Pyrazole aldehyde with 2-aminophenol

\section{Experimental}

All the chemicals used were of AR grade. Cobalt(II), Nickel(II) and Copper(II) used as acetate salts were of Merck. Pyrazole aldehyde was synthesized by very well-known Vilsmeier- Haak ${ }^{9}$ 
reaction and purified by usual separation methods. Elemental analyses were carried out on EURO EA-3000RS-232. IR spectra were recorded on 8400 FTIR Simadzu Spectrometer. ${ }^{1} \mathrm{H}$ NMR spectra of the ligand and complexes in DMSO-d6were recorded on a Bruker Advance II 400 Spectrometer at room temperature using TMS as internal standard. UV-Visible spectra were recorded on Shimadzu, Pharmaspec UV-1700 UV visible spectrometer. Mass spectra of ligands were recorded on GC-MS QP-2010 spectrometer, The ESI mass spectra of metal complexes were carried out using a micro mass Q-T of Micro spectrometer. Thermal analyses have been carried out by using Schimadzu (TGA-50H) from room temperature to $1000{ }^{\circ} \mathrm{C}$ under heating rate of $15^{\circ} \mathrm{C} \mathrm{min}^{-1}$.

Synthesis of 2-((3-(3-Substituted)-1-phenyl-1H-yrazol-4yl) methylene amino) phenol Schiff base was synthesized by using a synthetic approach. An ethanolic solution of $o$-amino phenol $(0.01 \mathrm{M})$ was added to the solution of Pyrazol aldehyde $(0.01 \mathrm{M}, 30 \mathrm{~mL}$ Methanol). The resulting reaction mixture was reflux for 8 hours. The progress of reaction was monitored by TLC (solvent system, benzene: acetone- $8: 2$ ). After completion of the reaction, the reaction mixture was poured in to crushed ice. The separated solid product was filtered and washed with cold saturated sodium bisulphate solution and recrystallized with ethanol.

\section{Synthesis of $\mathrm{Cu}(\mathrm{II})$ and $\mathrm{Co}(\mathrm{II})$ complexes}

A solution of the metal(II) acetate $(0.005 \mathrm{M})$ in minimum amount of ethanol was added to an ethanolic solution of the ligand $(0.01 \mathrm{M}, 20 \mathrm{~mL})$. The mixture was refluxed for $48 \mathrm{~h}$ on a boiling water bath. The volume was reduced to half and precipitated complex washed with water then recrystallized from hot methanol and dried in vacuum.

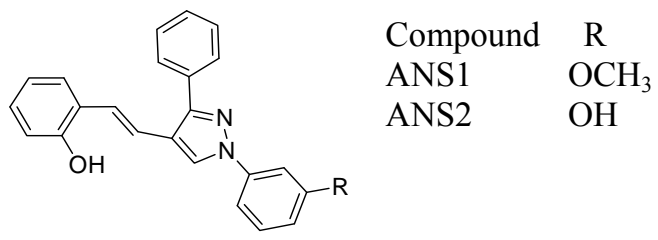

Figure 1. Structure of the Schiff bases

\section{Physical and spectral characterization of schiff base}

ANS1: 2-((3-(3-methoxyphenyl)-1-phenyl-1H-pyrazol-4-yl) methylene amino) phenol Colour: Brown; M.P: $148{ }^{0} \mathrm{C}$; Anal. Calcd. For $\mathrm{C}_{23} \mathrm{H}_{19} \mathrm{~N}_{3} \mathrm{O}_{2}(369.15 \mathrm{~g} / \mathrm{mol}): \mathrm{C}, 74.78 \%$; H, 5.18\%; N, 11.37\%; O, 8.66\%; Found: C, 74.14\%; H, 5.29\%; N, 11.30\%; O,8.44\%; MS $(\mathrm{m} / \mathrm{z}): 369.15(\mathrm{M}) ; \mathrm{IR}\left(\mathrm{KBr}, \mathrm{cm}^{-1}\right): v(-\mathrm{OH}) 3412 ; v(-\mathrm{HC}=\mathrm{N}) 1683 ; v(\mathrm{~N}-\mathrm{N}) 1078 ; v(\mathrm{Ar}-\mathrm{C}-\mathrm{H})$ 3076; $v\left(\mathrm{Ar}-\mathrm{OCH}_{3}\right) 2825 v(\mathrm{Ar}-\mathrm{C}=\mathrm{C}) 1487 ;{ }^{1} \mathrm{H}$ NMR $\left(\mathrm{DMSO}-\mathrm{d}_{6}\right): \delta$ ppm 9.21, (s, 1H, OH); 8.68, $(\mathrm{s}, 1 \mathrm{H},-\mathrm{HC}=\mathrm{N}) ; 8.5,(\mathrm{~s}, 1 \mathrm{H}, \mathrm{Ar}-\mathrm{H}) ; 7.90-7.92,(\mathrm{~d}, 2 \mathrm{H}, \mathrm{Ar}-\mathrm{H}) ; 7.69-7.71(\mathrm{~d}, 2 \mathrm{H}, \mathrm{Ar}-\mathrm{H}) ; 7.47-$ 7.51(t, 2H, Ar-H), 7.30-7.36 (m, 1H, Ar-H), 7.15-7.17 (d, 1H, Ar-H),6.97-7.06(m,3H, Ar-H), $6.8(\mathrm{~s}, 1 \mathrm{H}, \mathrm{Ar}-\mathrm{H}) ; 6.67-6.81(\mathrm{t}, 1 \mathrm{H}, \mathrm{Ar}-\mathrm{H}) ;{ }^{13} \mathrm{C}$ NMR $\left(\mathrm{DMSO}-\mathrm{d}_{6}\right): \delta p p m 184(-\mathrm{HC}=\mathrm{N}), 55.02(\mathrm{O}-$ $\left.\mathrm{CH}_{3}\right) ; 113.7,114.58,115,117.87,118.99,119.43,120.06,123.06,124.49,126.71 .127 .06,129.28$, 134.44, 129.35, 129.67, 137.29, 139.05, 144.07, 151.30, 152.37, 159.62, (Ph).

ANS2: 2-((3-(3-hydroxyphenyl)-1-phenyl-1H-pyrazol-4-yl) methylene amino) phenol Colour: Off white, M.P: $192{ }^{\circ} \mathrm{C}$; Anal. Calcd. For $\mathrm{C}_{22} \mathrm{H}_{17} \mathrm{~N}_{3} \mathrm{O}_{2}$ Exact Mass: $355.39 \mathrm{~g} / \mathrm{MolC}$, $74.35 \%$; H, 4.82\%; N, 11.82\%; O, 9.00\%; Found C, 74.32\%; H, 4.78\%; N, $11.80 \%$; O, 9.2\%; MS (m/z): $355.13(\mathrm{M}) ; \operatorname{IR}\left(\mathrm{KBr}, \mathrm{cm}^{-1}\right): v(-\mathrm{OH}) 3348, v(-\mathrm{HC}=\mathrm{N}) 1612, v(\mathrm{~N}-\mathrm{N}) 1060 ; \mathrm{v}(\mathrm{Ar}-\mathrm{C}-\mathrm{H})$ 
3049; $v(\mathrm{Ar}-\mathrm{C}=\mathrm{C}) 1491 ;{ }^{1} \mathrm{H}$ NMR (DMSO-d6): $\delta p p m 9.66 \quad(\mathrm{~s}, 1 \mathrm{H},-\mathrm{OH}$ Ar), 8.68, (s, 1H, $\mathrm{HC}=\mathrm{N}) ; 7.92-7.94,(\mathrm{~d}, 2 \mathrm{H}, \mathrm{Ar}-\mathrm{H}), 7.75-7.77,(\mathrm{~d}, 1 \mathrm{H}, \mathrm{Ar}-\mathrm{H}), 7.50$ (s, 2H, Ar-H); 7.35 (s, $1 \mathrm{H}, \mathrm{Ar}-\mathrm{H}) ; 6.88-6.94,(\mathrm{~m}, 2 \mathrm{H}, \mathrm{Ar}-\mathrm{H}) ; 6.78,(\mathrm{~s}, 1 \mathrm{H}, \mathrm{Ar}-\mathrm{H}) ;{ }^{13} \mathrm{C}$ NMR $\left(\mathrm{DMSO}-\mathrm{d}_{6}\right)$ : Sppm198.96 $(\mathrm{HC}=\mathrm{N}) ; 114.34 ; 115.25,115.52,118.27,118.55,119.02,119.40$, $119.95,121.84,122.80,126.75,126.97,129.25,129.72,129.99,137.50,139.08,150.74$, $151.15,152.76,158.01(\mathrm{Ph})$.

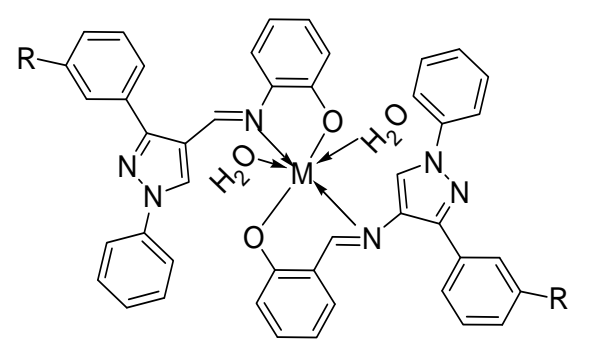

$\begin{array}{lll}\text { Complex } & \mathbf{M} & \mathbf{R} \\ \text { ARG1 } & \mathrm{Cu} & -\mathrm{OCH}_{3} \\ \text { ARG2 } & \mathrm{Co} & -\mathrm{OCH}_{3} \\ \text { ARG3 } & \mathrm{Cu} & -\mathrm{OH} \\ \text { ARG4 } & \mathrm{Co} & -\mathrm{OH}\end{array}$

Figure 2. Structure of metal complexes of Schiff bases

\section{Characterization of metal complexes}

Copper(II) complex of 2-((3-(3-methoxyphenyl)-1-phenyl-1H-pyrazol-4-yl) Methylene amino) phenol [ARG1]

Colour: Dark brown, Anal. Calcd. For $\mathrm{C}_{46} \mathrm{H}_{40} \mathrm{CuN}_{6} \mathrm{O}_{6}(835.23 \mathrm{~g} / \mathrm{mol})$ : C, 66.06\%; H, 4.82\%; $\mathrm{Cu}, 7.60 \%$; N, 10.05\%; O, 11.48\%; Found: $\mathrm{C}, 65.98 \% ; \mathrm{H}, 4.92 \%$; $\mathrm{Cu}, 7.20 \%$; N, 9.95\%; O, 11.28\%; ESI MS (m/z): $835.23(\mathrm{M})^{+}\left(\mathrm{CuL}_{2} \cdot \mathrm{nH}_{2} \mathrm{O}\right) ; \mathrm{IR}\left(\mathrm{KBr}, \mathrm{cm}^{-1}\right): v(-\mathrm{OH}) 3412 ; v(\mathrm{C}=\mathrm{N})$ 1593; $v(\mathrm{~N}-\mathrm{N}) 1078 ; v(\mathrm{Ar}-\mathrm{C}-\mathrm{H}) 3076 ; v(\mathrm{Ar}-\mathrm{C}=\mathrm{C}) 1487 ; v\left(-\mathrm{OCH}_{3}\right) 2825 ; v(\mathrm{Cu}-\mathrm{N}) 534$; UVVis:(DMF) $\left(\lambda_{\max } / \mathrm{nm}\right)$ : ,300,434,791; TGA wt. loss in \%(temp.): $5.04\left(130{ }^{\circ} \mathrm{C}\right) ; 7.61(236.8$ $\left.{ }^{\circ} \mathrm{C}\right) ; 14.03\left(300{ }^{\circ} \mathrm{C}\right) ; 18.12\left(400{ }^{\circ} \mathrm{C}\right) ; 25.54\left(500{ }^{\circ} \mathrm{C}\right) ; 87.0\left(610^{\circ} \mathrm{C}\right) ; 88.5\left(700{ }^{\circ} \mathrm{C}\right) ; 89.0$ $\left(800{ }^{\circ} \mathrm{C}\right) ; 93.1\left(950{ }^{\circ} \mathrm{C}\right)$.

Cobalt(II) complex of 2-((3-(3-methoxyphenyl)-1-phenyl-1H-pyrazol-4-yl) methylene amino)phenol [ARG2]

Colour: Pink, Anal. Calcd. For $\mathrm{C}_{46} \mathrm{H}_{40} \mathrm{CoN}_{6} \mathrm{O}_{6}(831.23 \mathrm{~g} / \mathrm{mol})$ : C, 66.42\%; H, 4.85\%; Co, $7.09 \%$; N, 10.10\%; O, 11.54\%. Found: C, 66.40\%; H, 4.75\%; Co, 7.01\%; N, 09.20\%; O, 11.24\%; ESI MS $(\mathrm{m} / \mathrm{z}): 834.1(\mathrm{M}+3)\left(\mathrm{CoL}_{2} \cdot \mathrm{nH}_{2} \mathrm{O}\right) ; \mathrm{IR}\left(\mathrm{KBr}, \mathrm{cm}^{-1}\right): v(-\mathrm{OH}) 3336 ; v(\mathrm{C}=\mathrm{N})$ 1599; $v(\mathrm{~N}-\mathrm{N}) 1030 ; v(\mathrm{Ar}-\mathrm{C}-\mathrm{H}) \quad 3037 ; v(\mathrm{Ar}-\mathrm{C}=\mathrm{C}) 1471 ; v\left(\left(-\mathrm{OCH}_{3}\right) 2883 ; v(\mathrm{Co}-\mathrm{N})\right.$ 530; $v$ (Co-O) 468; UV-Vis:(DMF) $\left(\lambda_{\max } / \mathrm{nm}\right): 364,431,439,727$. TGA wt. loss in \%(temp.): 3.2 $\left(100{ }^{\circ} \mathrm{C}\right) ; 5.5\left(200.0{ }^{\circ} \mathrm{C}\right) ; 8.4\left(257^{\circ} \mathrm{C}\right) ; 21.5\left(400^{\circ} \mathrm{C}\right) ; 29.8\left(502{ }^{\circ} \mathrm{C}\right) ; 49.5\left(600{ }^{\circ} \mathrm{C}\right) ; 81.0$ $\left(700{ }^{\circ} \mathrm{C}\right) ; 97.0\left(778^{\circ} \mathrm{C}\right)$.

Copper(II) complex of 2-((3-(3-hydroxyphenyl)-1-phenyl-1H-pyrazol-4-yl) methylene amino)phenol [ARG3]

Colour: Gray, Anal. Calcd. For $\mathrm{C}_{44} \mathrm{H}_{34} \mathrm{CuN}_{6} \mathrm{O}_{6}(806.32 \mathrm{~g} / \mathrm{mol}): \mathrm{C}, 65.54 \%$; H, 4.25\%; $\mathrm{Cu}$, $7.88 \%$; N, 10.42\%; O, 11.91\%. Found C, 65.51\%; H, 4.20\%; Cu, 7.98\%; N, 10.40\%; O, $11.98 \%$. ESI MS $(\mathrm{m} / z): 808(\mathrm{M}+2)\left(\mathrm{CuL}_{2} \cdot \mathrm{nH}_{2} \mathrm{O}\right) ; \mathrm{IR}\left(\mathrm{KBr}, \mathrm{cm}^{-1}\right): v(\mathrm{Ar}-\mathrm{OH}) 3402 ; v(\mathrm{C}=\mathrm{N})$ 1593; v(N-N) 1084; v(Ar-C-H) 3105-2818; v(Ar-C=C) 1475; v(Cu-N) 547; v(Cu-O) 416. UV-Vis:(DMF) $\left(\lambda_{\max } / \mathrm{nm}\right): 314,333,417,781$. TGA wt. loss in $\%$ (temp.): $5.2\left(130{ }^{\circ} \mathrm{C}\right)$; $11.5\left(270{ }^{\circ} \mathrm{C}\right) ; 40\left(280{ }^{\circ} \mathrm{C}\right) ; 74.2\left(490{ }^{\circ} \mathrm{C}\right) ; 90\left(530{ }^{\circ} \mathrm{C}\right)$. 
Cobalt(II) complex 2-((3-(3-hydroxyphenyl)-1-phenyl-1H-pyrazol-4-yl)methylene amino) phenol [ARG4]

Colour: Redish brown, Anal. Calcd. For $\mathrm{C}_{44} \mathrm{H}_{34} \mathrm{CoN}_{6} \mathrm{O}_{6}$ (801.71/mol): C, 65.92\%; H, 4.27\%; Co, 7.35\%; N, 10.48\%; O, 11.97\%. Found: C, 65.87\%; H, 4.21\%; Co, 7.25\%; N, 10.35\%; O, $11.87 \%$. ESI MS $(\mathrm{m} / \mathrm{z}): 806\left(\mathrm{CoL}_{2}\right)(\mathrm{M}+4)$; IR $\left(\mathrm{KBr}, \mathrm{cm}^{-1}\right): v(\mathrm{Ar}-\mathrm{OH}) 3245 ; v(\mathrm{C}=\mathrm{N}) 1591$; $v(\mathrm{~N}-\mathrm{N}) \quad 1145 ; \quad v(\mathrm{Ar}-\mathrm{C}-\mathrm{H}) \quad 2979 ; \quad v(\mathrm{Ar}-\mathrm{C}=\mathrm{C}) \quad 1473 ; v(\mathrm{Co}-\mathrm{N}) \quad 536 ; v(\mathrm{Co}-\mathrm{O})$ 493. UVVis:(DMF) $\left(\lambda_{\max } / \mathrm{nm}\right)$ : UV-Vis:(DMF) $\left(\lambda_{\max } / \mathrm{nm}\right): 415,373,333,318$. TGA wt. loss in \%(temp.): $4.2\left(107^{\circ} \mathrm{C}\right) ; 8.7\left(224.6{ }^{\circ} \mathrm{C}\right) ; 40\left(350.8^{\circ} \mathrm{C}\right) ; 73.5\left(494.4^{\circ} \mathrm{C}\right) ; 78.3\left(700{ }^{\circ} \mathrm{C}\right)$.

\section{Results and Discussion}

With the help of spectral characterization of metal complexes we can justified the formation and the structure of metal complexes. The most important bands in the infrared spectra of the copper(II) complex of synthesized Schiff base are along within their tentative assignment are given in summery. The position of these bands was helpful to detect the bonding sites of all ligand molecules interacted with metal. Infrared spectra of the ligands show strong bands at $1683 \mathrm{~cm}^{-1}$ and 1612 respectively which may be assigned to the symmetric $v(\mathrm{C}=\mathrm{N})$ vibrations for all metal complexes. These frequencies are shifted towards lower wave number by $15-30 \mathrm{~cm}^{-1}$ in spectra of all metal complexes, suggesting the coordination of nitrogen of the azomethine group to the central metal atom in these complexes. The metal-nitrogen bond was detected by appearing frequencies in the region $540-485 \mathrm{~cm}^{-1}$ from the IR data. The IR spectra of the metal(II) complex exhibited a broad band at the range of $3200-3417 \mathrm{~cm}^{-1}$ that are attributed to substituted -OH group and -OH of crystal water molecules. From the IR data, it can be inferred that the ligand involved in the Complexation as a bidentate ligand which coordinated with metal ions through the oxygen of hydroxyl group of amino phenol and azomethine $\mathrm{N}$ atom.

In the ${ }^{1} \mathrm{H}$ NMR spectra of the copper(II) complex of 2-((1,3-diphenyl-1H-pyrazol-4yl)methyleneamino) phenol the signals of the - $\mathrm{OH}$ protons were observed as singlets at $\delta$ $\sim 9.28 \mathrm{ppm}$ in the free ligand this signals disappears after Complexation. The signals of the ($\mathrm{HC}=\mathrm{N}$ ) proton which appear as singlet at $7.9 \mathrm{ppm}$ in the complex. The signal as compare to ligand show a shift to up field in $\delta 0.03-0.80 \mathrm{ppm}$ after Complexation. This shift indicates the coordination of the imine nitrogen to the metal centre. Distortion in ${ }^{1} \mathrm{H}$ NMR spectra of complexes shows the complex formation.

The electronic absorption spectra are often very helpful in the evaluation of results furnished by other methods of structural investigation. The charge transfer band of ARG1, ARG2, ARG3 and ARG4 observed at 434 334, 417 and $318 \mathrm{~nm}$ respectively. The d-d transition of the complex was also recorded in visible region by concentrating the solution. The bands appeared at $791 \mathrm{~nm}$ and $781 \mathrm{~nm}$ is assigned to ${ }^{2} \mathrm{~T}_{2 \mathrm{~g}} \leftarrow{ }^{2} \mathrm{E}_{\mathrm{g}}$ transition in ARG1 and ARG3 complexes. The bands appeared at 431, 439, $727 \mathrm{~nm}$ is assigned to ${ }^{4} \mathrm{~T}_{1 \mathrm{~g}}(\mathrm{~F}) \rightarrow{ }^{4} \mathrm{~T}_{2 \mathrm{~g}}(\mathrm{~F})$, ${ }^{4} \mathrm{~T}_{1 \mathrm{~g}}(\mathrm{~F}) \rightarrow{ }^{4} \mathrm{~A}_{2 \mathrm{~g}}(\mathrm{~F}),{ }^{4} \mathrm{~T}_{1 \mathrm{~g}}(\mathrm{~F}) \rightarrow{ }^{4} \mathrm{~T}_{1 \mathrm{~g}}(\mathrm{P})$ transition in $\mathrm{ARG} 2$ and bands appeared at $415,373,333 \mathrm{~nm}$ attributed to ${ }^{4} \mathrm{~T}_{1 \mathrm{~g}}(\mathrm{~F}) \rightarrow{ }^{4} \mathrm{~T}_{2 \mathrm{~g}}(\mathrm{~F}),{ }^{4} \mathrm{~T}_{1 \mathrm{~g}}(\mathrm{~F}) \rightarrow{ }^{4} \mathrm{~A}_{2 \mathrm{~g}}(\mathrm{~F}),{ }^{4} \mathrm{~T}_{1 \mathrm{~g}}(\mathrm{~F}) \rightarrow{ }^{4} \mathrm{~T}_{1 \mathrm{~g}}(\mathrm{P})$ transition in ARG4 respectively.

The TGA analysis of all the metal complexes was carried out within a temperature range from room temperature up to $1000{ }^{\circ} \mathrm{C}$. The data from thermo gravimetric analysis clearly indicated that the decomposition of the complex proceed in several steps. Hydration water molecules were lost in between $30{ }^{\circ} \mathrm{C}-120^{\circ} \mathrm{C}$. The coordinated water molecules were liberated in between $120^{\circ} \mathrm{C}-200{ }^{\circ} \mathrm{C}$, There is continuous change up to $\sim 350{ }^{\circ} \mathrm{C}$ after that there is another break in the curves due to complete decomposition of organic ligand, the remaining 
ligand were removed from the coordination sphere at $\sim 600^{\circ} \mathrm{C}$. Finally the metal oxides were formed at $\sim 650-900^{\circ} \mathrm{C}$. The degradation pathway for the complex may be represented as follows.

$$
\begin{gathered}
{\left[\mathrm{M}\left(\mathrm{L}_{2}\right)\left(\mathrm{H}_{2} \mathrm{O}\right)_{\mathrm{n}}\right] \cdot \mathrm{nH}_{2} \mathrm{O} \stackrel{30-90^{\circ} \mathrm{C}}{\longrightarrow}\left[\mathrm{M}\left(\mathrm{L}_{2}\right)\left(\mathrm{H}_{2} \mathrm{O}\right)_{\mathrm{n}}\right]+\mathrm{nH}_{2} \mathrm{O}} \\
{\left[\mathrm{M}\left(\mathrm{L}_{2}\right)\left(\mathrm{H}_{2} \mathrm{O}\right)_{\mathrm{n}}\right] \stackrel{100-190^{\circ} \mathrm{C}}{\longrightarrow}\left[\mathrm{M}\left(\mathrm{L}_{2}\right)\right]+\left(\mathrm{H}_{2} \mathrm{O}\right)_{\mathrm{n}}} \\
{\left[\mathrm{M}\left(\mathrm{L}_{2}\right)\right] \stackrel{190-350{ }^{\circ} \mathrm{C}}{\longrightarrow}[\mathrm{ML}]+\mathrm{L}} \\
{[\mathrm{ML}] \stackrel{350-650{ }^{\circ} \mathrm{C}}{\longrightarrow} \mathrm{MO}+\mathrm{L}}
\end{gathered}
$$

(Where $\mathrm{n}=0,1$ or 2 and $\mathrm{M}=\mathrm{Cu} \& \mathrm{Co}$ ).

The copper(II) complexes show the magnetic moment values 1.74 and 1.79 BM respectively correspond to the values normally observed for octahedral copper(II) compound. The cobalt(II) complex show magnetic moment 4.81 and 4.45 BM respectively in accordance with a high spin configuration showing the presence of octahedral environment around the cobalt(II) ion in the complex.

\section{Conclusion}

The complexes are coloured and the ratio of metal ligand is 1:2 in all complexes. Conductance value indicate that non electrolytic nature of complexes. TGA of metal complexes indicated two coordinated water molecule. The value of magnetic susceptibility, electronic spectral data and TGA suggested plausible octahedral structure of metal complexes.

\section{Acknowledgement}

Authors are thankful to Prof. and Head Deparment of Chemistry Saurashtra university for providing me necessary facilities, UGC New Delhi for the awrd of maritorious fellowship. SAIF Chandigarh for ESI mass, ${ }^{1} \mathrm{HNMR}$ and ${ }^{13} \mathrm{CNMR}$ analysis.

\section{References}

1. Singh D P, Kumar R, Mehani R and Verma S K, J Serb Chem Soc., 2006, 71, 939.

2. Deepa K, Madhu N T and Radhakrishnan P K, Synth React Inorg Met.-Org Chem., 2005, 35(10), 883-888; DOI:10.1080/15533170500358135

3. Chohan Z H, Pervez H, Rauf A, Khan K M and Supuran C T, J Enzyme Inhib Med Chem., 2004, 19(5), 417-423.

4. Karvembu R and Natarajan K, Polyhedron, 2002, 21(2), 219-223; DOI:10.1016/S0277-5387(01)00980-9

5. Ali S A, Soliman A A, Aboaly M M and Ramadan R M, J Coord Chem., 2002, 55(10), 1161-1170; DOI:10.1080/0095897021000023509

6. Chatterjee D, Mitra A and Roy B C, J Mol Cat A: Chem., 2000, 161(1-2), 17-21; DOI:10.1016/S1381-1169(00)00269-7

7. Brenno A D N and Alexandre A M L, Molecules, 2009, 14(5), 1725-1746; DOI:10.3390/molecules14051725

8. Tatiana D R, Giampiero S, Maurizio P, Saison-Behmoaras T, Alexandre B and Cacciari B, Current Med Chem., 2005, 12(1), 71-88; DOI:10.2174/0929867053363603

9. (a) Elguero J, In Comprehensive Heterocyclic Chemistry; Katritz-ky A R, Rees C W and Scriven E F V, Eds., Pergamon: Oxford, 1996, 3, 1. For selected recent reviews, refer: (b) Dolzhenko A V, Dolzhenko A V and Chui W K, Heterocycles, 2008, 75(7), 1575-1622; DOI:10.3987/REV-08-629 (c) Lam-berth C, Heterocycles, 2007, 71(7), 1467-1502; DOI:10.3987/REV-07-613

10. Halcrow M A, Dalton Trans., 2009, 2059-2073; DOI:10.1039/B815577A

11. Ambika Shrivastava and Singh R M, Indian J Chem., 2005, 44B, 1868-1875. 